\title{
Nutrient Uptake and Biological Activity in Tomato by Zinc Solubilizing Bacterial (ZSB) Isolates
}

\author{
D.N. Vidyashree ${ }^{1 *}$, R. Muthuraju ${ }^{1}$ and P. Panneerselvam ${ }^{2}$ \\ ${ }^{1}$ Department of Agricultural Microbiology, University of Agricultural Sciences, GKVK, \\ Bengaluru-560 065, Karnataka, India \\ ${ }^{2}$ ICAR-National Rice Research Institute, Cuttack-753006, Odisha, India \\ *Corresponding author
}

\begin{tabular}{|l|}
\hline Ke y w o r d s \\
$\begin{array}{l}\text { Deficiency, Zinc } \\
\text { solubilizing bacteria, } \\
\text { Bacillus aryabhattai, } \\
\text { biofortification of Zn, } \\
\text { Soil enzymes }\end{array}$ \\
\hline Article Info \\
\hline $\begin{array}{l}\text { Accepted: } \\
\text { 07 April } 2018 \\
\text { Available Online: } \\
\text { 10 May 2018 }\end{array}$ \\
\hline \hline
\end{tabular}

\section{A B S T R A C T}

Zinc deficiency not only affects crop yields, but also nutritional quality and human health. Microbial transformation of unavailable forms of soil zinc to plant available zinc is an important approach contributing to plant zinc nutrition. Therefore, Nutrient uptake and biological activity in Tomato crop by zinc solubilizing bacterial isolates was tested under glass house condition. The study consisted of six treatments, each with five replications, including five different zinc solubilizing bacteria and uninoculated control, out of five bacteria $B$. aryabhattai was used as reference strain. The results revealed that tomato seedlings treated with $B$. aryabhattai and Bacillus sp. (PAN-TM1) substantially decreased rhizosphere $\mathrm{pH}$ and increased the macro and micro nutrient concentration in rhizosphere, plant and tomato fruit especially zinc concentration in the fruit (31.1 and $29.3 \mathrm{ppm}$ respectively). Further biological activity viz., dehydrogenase, urease, acid and alkaline phosphatase, soil respiration and soil microbial biomass carbon was also found to be increased significantly with the B. aryabhattai and Bacillus sp.(PAN-TM1) treated seedlings as compared to uninoculated treatment. This assumes significance as the increased zinc concentration found in this study has large implications in terms of overcoming zinc malnutrition. ZSB isolates i.e. B. aryabhattai and Bacillus sp. (PANTM1) substantially influenced mobilization of zinc and its concentration in edible portion, which can be utilized as bio-inoculants for biofertilization and biofortification in the sustainable crop production practices.

\section{Introduction}

Micronutrients are important for the optimum growth and productivity of the plants. Though these elements are required in critical amounts, they are very important for plant development and for profitable crop production because they work 'behind the scene' as activators of many plant functions.
Of the several micronutrients that increase plant growth and productivity zinc (Zn) plays a vital role. Zinc is one of the imperative micronutrient required relatively in small concentrations $\left(5-100 \mathrm{mg} \mathrm{kg}^{-1}\right)$ in tissues for healthy growth and reproduction of plants. $\mathrm{Zn}$ is an important component of enzymes that drive and increase the rate of many important metabolic reactions involved in crop growth 
and development (Potarzycki and Grzebisz, 2009). Inadequate supply of $\mathrm{Zn}$ to the plant result in the cessation of physiological functions which lead to the development of visible symptoms of stress such as interveinal chlorosis, bronzing of chlorotic leaves, small and abnormally shaped leaves, stunting and rosetting. Zn deficiency significantly affects the root system including root development (Fageria et al., 2002). The flowering and fruiting process were greatly reduced under severe $\mathrm{Zn}$ deficiency. Quality of harvested products, plant susceptibility to injury by high or light temperature intensity and to infection by fungal diseases can also increase by $\mathrm{Zn}$ deficiency (Cakmak, 2000).

The major reason for the widespread occurrence of $\mathrm{Zn}$ deficiency problems in crop plants is attributed to low solubility of $\mathrm{Zn}$ in soils rather than a low total amount of $\mathrm{Zn}$. External addition of soluble $\mathrm{Zn}$ to alleviate deficiency results in the transformation of about 96- $99 \%$ to various fractions of unavailable forms and about $1-49 \%$ is left as available fraction in the soil. So the water soluble $\mathrm{Zn}\left(\mathrm{ZnSO}_{4} .7 \mathrm{H}_{2} \mathrm{O}\right)$ advocated and applied in the soil cannot be detected beyond 15 days of period (Rattan and Shukla, 1991) and become unavailable which make the $\mathrm{Zn}$ nutrition to the plants critical. This requires a system that releases the required quantity of $\mathrm{Zn}$ that are converted to unavailable state and retained in the soil to available form. Microbes are potential alternate that could cater plant zinc requirement by solubilising the complex zinc in soil. Several genera of rhizobacteria belonging to Pseudomonas spp. and Bacillus spp. are reported to solubilise zinc. Microbes solubilize the metal forms by protons, chelated ligands, and oxidoreductive systems present on the cell surface and membranes. These bacteria also exhibit other traits beneficial to plants, such as production of phytohormones, antibiotics, siderophores, vitamins, antifungal substances, and hydrogen cyanide (Saravanan et al., 2003). Thus microbial inoculants will be an alternative approach to overcome constraints due to synthetic fertilizer and to revive soil's fertility resulting in the intensive farming. Since zinc is a limiting factor in crop production, the study on zinc solubilization by bacteria has an immense importance in zinc nutrition to plants. Moreover, it is essential to find out a simple way to enhance zinc concentrations in foodsto solve malnutrition problem in our country. In view of above, the present investigation was undertaken in order to overcome the zinc deficiency in soils as well as to enhance zinc concentration in final produce by using zinc solubilizing bacteria (ZSB). Hence, this study was carried out to know the effect of ZSB on nutrient uptake and biological activity of tomato crop.

\section{Materials and Methods}

The glass house experiment was conducted in Microbiology Laboratory, Division of Soil Science and Agricultural Chemistry, ICARIIHR, Hesaraghatta, Bengaluru, Karnataka. The low zinc containing soil was collected from third block of IIHR, Hesaraghatta and the soil had the following characteristics. $\mathrm{pH}$ : 6.62, EC $\left(\mathrm{dsm}^{-1}\right): 0.535, \mathrm{OC} \%: 0.48, \mathrm{~N}(\mathrm{ppm})$ : 77.76, P (ppm): 7.16, K (ppm): 134.4, Ca (ppm): 550.8, $\mathrm{Mg}(\mathrm{ppm}):$ 100.3, Fe (ppm): 48.2, Cu (ppm): 2.31, Mn (ppm): 50.36, Zn (ppm):0.75.Further the soil was sieved to remove debris and sterilized for three consecutive days later on filled in to the pots of $30 \mathrm{~cm}$ diameter at the rate of $20 \mathrm{~kg} /$ pot. The seeds of tomato (ArkaRakshak) used in the study were collected from IIHR and were sown in protray containing cocopeat. After germination, 21 days old seedling with well root development and uniform growth were selected and transplanted to the pots. After 5 days of planting $20 \mathrm{gm}$ of lignite based cultures containing population of $2.3 \mathrm{x}$ $10^{9} \mathrm{cfu} / \mathrm{g}$ were added. The pots were uniformly watered regularly to maintain optimum 
moisture content in the soil and the recommended dose of fertilizer for hybrid tomato (180:120:180 kg NPK per ha) was given. The plants were destructively sampled and soils were sampled from each pot at 45 days after planting (DAP). Soil and plant samples were analyzed for nutrient concentrations. Soil samples were analyzed for enzyme activities, organic carbon and biomass carbon and nutrient concentrations. One plant per pot was maintained throughout the experiment.

\section{Treatments details}

The pot culture experiment consisted of six treatments with five replication, which includes five different ZSB and uninoculated control, out of five bacteria Bacillus aryabhattai was used as reference strain.

These ZSB isolates were isolated from stone quarry dust powder and also the well characterized five PGPR bacteria viz., Bacillus aryabhattai, Pseudomonas taiwenensis, Bacillus sp. (PAN-TM1), Enterobacter sp.-2 and Bacillus aerophilus were received from the Culture Collection Centre, Microbiology Laboratory, Division of Soil Science and Agricultural Chemistry, ICAR- IIHR, Hesaraghatta, Bengaluru, Karnataka. These bacterial isolates were examined for their ability to solubilize zinc from insoluble Zinc source and their potential in enhancing the zinc content in tomato under pot culture studies. The details of treatments are as follows,

Estimation of nutrient content in rhizosphere soil, plant and fruit of tomato inoculated with ZSB

\section{Soil nutrient analysis}

The soil samples were collected at 45 days after planting were analyzed chemically for various characteristics. The soil $\mathrm{pH}$, electrical conductivity (EC), Organic carbon (OC) and available potassium $(\mathrm{K})$ was estimated by standard protocol developed by Jackson (1973). Available nitrogen was determined by macro distillation of the sample following alkaline permanganate method as suggested by Subbiah and Asija (1956). Available phosphorus was extracted with Bray's No.1 extractant $\left(0.03 \mathrm{~N} \mathrm{NH}_{4} \mathrm{~F}+0.025 \mathrm{~N} \mathrm{HCl}\right)$. The phosphorus in the extract was determined by chloro stannous reduced molybdo-phosphoric blue colour method in $\mathrm{HCl}$ acid medium. The intensity of blue colour was read at $660 \mathrm{~nm}$ using a spectrophotometer (Bray and Kurtz, 1945).

Exchangeable Calcium and Magnesium were determined by complexometric titration method using appropriate indicators (Baruah and Barthakur, 1997). The method developed by Lindsay and Norwell (1978) using DTPA extractant (Diethylene triaminepenta acetic acid) was followed for the estimation of $\mathrm{Zn}$, $\mathrm{Cu}, \mathrm{Mn}$ and $\mathrm{Fe}$. Ten grams soil was shaken with $20 \mathrm{ml}$ of DTPA extractant for 2 hours for the extraction of micronutrient cations. Atomic absorption spectrophotometer was used for measuring the concentration.

\section{Plant and fruit nutrient analyses}

Dried plant and fruit samples were finely ground by using willey stainless steel millto amorphous powder and one gram was taken in $150 \mathrm{~mL}$ conical flask containing $10 \mathrm{ml}$ nitric acid $\left(\mathrm{HNO}_{3}\right)$ and perchloric acid $\left(\mathrm{HClO}_{4}\right)$ in 9:4 ratios. The flasks were placed on a hot plate and digested at $300^{\circ} \mathrm{C}$ until the entire plant material turned colorless. The extract was taken in $100 \mathrm{ml}$ volumetric flask and the volume was made to $100 \mathrm{ml}$ with distilled water. These samples were used for estimation of $\mathrm{P}, \mathrm{K}, \mathrm{Ca}, \mathrm{Mg}$ and micronutrients $\mathrm{Fe}, \mathrm{Cu}$, $\mathrm{Mn}$ and $\mathrm{Zn}$ by using standard procedures. Phosphorous was quantified by forming 
yellow color phosphovanadomolybdate complex using spectrophotometer at 430nm (Baruah and Barthakur, 1997). Potassium was estimated by feeding the diluted plant and fruit extract to flame photometer as described by Jackson (1973).

Total nitrogen content was estimated by taking About 1 gram of powdered plant and fruit samples were digested with concentrated sulphuric acid and digestion mixture $\left(\mathrm{K}_{2} \mathrm{SO}_{4}\right.$ : $\mathrm{CuSO}_{4} .5 \mathrm{H}_{2} \mathrm{O}$ : Selenium in 100: 20: 1 proportion) till a green residue was obtained. The digested material was distilled by micro Kjeldhal distillation method. The liberated ammonia was trapped in boric acid and then nitrogen was estimated by titration against standard sulphuric acid (Piper, 1966). Similarly, micronutrients such as iron, copper, manganese, zinc, calcium and magnesium were estimated by atomic absorption spectrophotometer.

Biological activity in rhizosphere soil of tomato

The soil samples were collected by completely uprooting the plants at 45 days after planting (DAP) and used for the determination of enzyme activities.

\section{Dehydrogenase activity}

Moistened soil sample (20 g) was incubated with $0.2 \mathrm{~g}$ CaCO3and $2 \mathrm{ml} 1 \%$ triphenyltetrazoilum chloride at $30^{\circ} \mathrm{C}$ for $24 \mathrm{~h}$. At theend of incubation period, soil sample was extracted with $25 \mathrm{ml}$ methanol. The microbial activity produces $\mathrm{H}^{+}$ions, which reduces triphenyl tetrazoilum chloride into triphenyl tetrazoilum formazan, which is red in colour. Dehydrogenase activity, the index of microbial activity was determined by measuring the intensity of red colour at 485 $\mathrm{nm}$ and expressed as $\mu \mathrm{g}$ of TPF released/g soil/hour (Tate and Terry, 1980).

\section{Phosphatase activity}

\section{Acid and alkaline phosphatase activity}

Phosphatase activity of soil sample was determined by following the procedure of Eizavi and Tabatabai (1977). 1 gm of soil sample was placed in $50 \mathrm{ml}$ Erlenmeyer flask to which $0.2 \mathrm{ml}$ toluene followed by $4 \mathrm{ml}$ of modified Universal buffer ( $\mathrm{pH}$ 6.5) was added. $1 \mathrm{ml}$ of para-nitrophenyl phosphate solution made in modified universal buffer was added to the flask and contents of the flasks were mixed by swirling for two minutes. The flasks were stoppered and incubated at $37^{\circ} \mathrm{C}$ for one hour. After incubation, $1 \mathrm{ml}$ of $0.5 \mathrm{M} \mathrm{CaCl}_{2}$ and $4 \mathrm{ml}$ of $0.5 \mathrm{M} \mathrm{NaOH}$ were added to the flask, swirled and filtered through Whatman No. 42 filter paper. The intensity of yellow colour developed was measured at $420 \mathrm{~nm}$ against the reagent blank using spectrophotometer. Controls were also performed for each soil sample following the same procedure described above except that the paranitrophenyl phosphate solution was added after the addition of $0.5 \mathrm{M} \mathrm{CaCl}_{2}$ and $0.5 \mathrm{M} \mathrm{NaOH}$ and just before filtration. P-Nitro phenol content of the supernatant was calculated by referring to a calibration graph plotted from the results obtained with standards containing $0,10,20,30,40$ and 50 $\mu \mathrm{g}$ of paranitrophenyl. The phosphatase activity in the soil samples were expressed as $\mu \mathrm{g}$ paranitrophenyl solution.

The alkaline phosphatase activity of the soil samples were determined by following the same procedure as that of acid phosphatase activity except that $\mathrm{pH}$ of modified universal buffer was adjusted to 11 .

\section{Soil urease activity}

Urease activity was determined by the following procedure described by Tabatabai and Bremner (1972). One gram of soil sample 
was taken in a $50 \mathrm{ml}$ volumetric flask to which $0.20 \mathrm{ml}$ toluene and $9 \mathrm{ml}$ THAM buffer was added and the flasks were swirled for few minutes to mix the contents. To the flask, $1 \mathrm{ml}$ of $0.2 \mathrm{M}$ urea solution was added and swirled again. Then the flask was stoppered and placed in an incubator, at $37^{\circ} \mathrm{C}$. After 2 hours, approximately $35 \mathrm{ml}$ of $\mathrm{Ag}_{2} \mathrm{SO}_{4}$ solution was added and was filtered. $20 \mathrm{ml}$ of aliquot was taken in $100 \mathrm{ml}$ distillation flask and $\mathrm{NH}_{4}-\mathrm{N}$ released with $0.2 \mathrm{~g} \mathrm{MgO}$ was determined using Kjeldahl distillation apparatus. Urease activity was expressed as $\mu \mathrm{g} \mathrm{NH}_{4}-\mathrm{N}$ released gram $^{-1}$ of compost hour ${ }^{-1}$.

\section{Soil respiration and substrate induced soil respiration}

Fifty gram sieved soil was taken (55\% WHC) in a beaker and placed it in a jar containing $25 \mathrm{ml} \mathrm{NaOH}(0.05 \mathrm{M})$ and made it air tight immediately by the lid. 2-5 jars with $\mathrm{NaOH}$ $(0.05 \mathrm{M})$ without soil sample used as control. The jars were incubated for 24 hours at $25^{\circ} \mathrm{C}$. Same method was used to determine the substrate induced soil respiration. In this case $0.5 \%$ glucose mixed with the soil sample and incubated for 4-6 hours at $22^{\circ} \mathrm{C}$. After 24 hours jars were opened and took out the beaker and washed external surface of the beaker with $\mathrm{CO}_{2}$ - free water to bring the $\mathrm{NaOH}$ solution completely in to the jar then added $5 \mathrm{ml}$ of barium chloride solution $(0.5 \mathrm{M})$ and some drop of phenolphthalein indicator and then titrated against $\mathrm{HCl}(0.05 \mathrm{M})$ under continuous stirring until the colour changes from pink to colourless. Then the rate of the respiration was calculated and expressed as $\mathrm{CO}_{2}-\mathrm{C} \mathrm{mg} / \mathrm{kg}$ soil/hour.

\section{Soil microbial biomass carbon}

Microbial biomass C (Biomass C) was determined by the chloroform fumigationextraction method, with $0.5 \quad \mathrm{M} \mathrm{K}_{2} \mathrm{SO}_{4}$ as extractant. The organic $\mathrm{C}$ of extracts was estimated by oxidation with potassium dichromate (Vance et al., 1987). The difference in $\mathrm{C}$ content of the fumigated and unfumigated extracts was converted to microbial biomass $\mathrm{C}$ (expressed in $\mathrm{mg} \mathrm{kg}^{-1}$ of dry soil) by applying a factor (Kc) of 0.45 (Jenkinson, 1988).

\section{Results and Discussion}

\section{Effect of zinc solubilizing bacterial isolates on rhizosphere nutrient content of tomato at 45 DAP}

There was a decline in the rhizosphere $\mathrm{pH}$ ranged from 5.95 to 6.52 with the inoculation of ZSB strains compared to uninoculated control (Table 1). Among the different ZSB inoculated treatments, $B$. aryabhattai acidify the rhizosphere solution to a greater extent and declined $\mathrm{pH}$ (5.95) as compared to uninoculated control (6.52). The electric conductivity (EC) was found to be nonsignificant among the different ZSB inoculated treatments. The organic carbon content in the rhizosphere was found to be significant, the highest was observed in $B$. aryabhattai $(0.79 \%)$ inoculated treatment followed by Enterobacter sp.-2 (0.77\%) inoculated plants. Significant differences of major nutrients were observed among the different treatments inoculated with ZSB isolates. Significantly highest N, P and K were recorded in the plants inoculated with $B$. aryabhattai (144.1, 18.9 and 120.2 ppm respectively) followed by Bacillus sp. (PANTM1) (140.9, 18.4 and 107.5 ppm respectively). The highest micro nutrient content viz., calcium, iron, zinc were observed in the treatments inoculated with $B$. aryabhattai (974.1, 180.2 and $4.27 \mathrm{ppm}$ respectively) which was significantly higher compare to all the other treatments, whereas the least micro nutrients was recorded in the rhizosphere of uninoculated control. The other micro nutrients viz., magnesium, copper and 
manganese content in rhizosphere of tomato revealed non-significant differences among the treatments as influenced by the zinc solubilizing bacterial isolates. However, the maximum magnesium (114.5ppm) content observed in the plants inoculated with $B$. aryabhattai whereas copper $(3.6 \mathrm{ppm})$ and manganese (160.6ppm) content in the plants inoculated with Bacillus sp. (PAN-TM1).

Effect of zinc solubilizing bacterial isolates on plant nutrient concentration of tomato at 45 DAP

Major and micro nutrients content of tomato plant at 45 days after planting was observed upon the inoculation of zinc solubilizing bacterial isolates. Significant differences of major plant nutrients concentration viz., $\mathrm{N}, \mathrm{P}$ and $\mathrm{K}$ were observed among the plants inoculated with zinc solubilizing bacterial isolates (Table 2). The treatment inoculated with $B$. aryabhattai recorded higher per cent of $\mathrm{N}$ and $\mathrm{P}$ (2.45 and $0.65 \%)$ as compared to other treatment. The potassium concentration was recorded more or less similar in Bacillus sp. (PAN-TM1) (5.3\%) and B. aryabhattai $(5.2 \%)$ inoculated plants.

Among the minor plant nutrients concentration of tomato at 45 days after planting, significant differences were observed in calcium, copper, manganese and zinc concentration of tomato plants among the various treatments.

The highest concentration of calcium, copper and zinc was recorded in the treatment inoculated with B. aryabhattai $(6.86 \%, 19.1$ and $56.3 \mathrm{ppm}$ respectively) as compared to other treatments, whereas Bacillus sp. (PANTM1) inoculated treatment recorded highest Mn content (85.1ppm). The highest magnesium and iron concentration in plants were noticed in $B$. aryabhattai treated plants (0.396\% and 373.6ppm).
Effect of zinc solubilizing bacterial isolates on fruit nutrient concentration of tomato at harvest

The results on the fruit nutrient concentration of tomato at harvest upon inoculation of efficient ZSB isolates reveals that, there was a significant difference in the major nutrients concentration in the tomato fruit (Table 3). The treatment inoculated with $B$. aryabhattai recorded significantly higher nitrogen, phosphorus and potassium (2.36, 0.34 and $3.58 \%$ respectively) which are statistically on par with the treatment Bacillus sp. (PANTM1) (2.28, 0.32 and $3.41 \%$ respectively). Among the micro nutrients, the significant concentration of calcium, magnesium, iron and zinc was recorded in the treatment inoculated with B. aryabhattai (3.89\%, $0.233 \%$, $134.1 \mathrm{ppm}$ and $31.1 \mathrm{ppm}$ respectively), followed by the treatment Bacillus sp. (PAN-TM1) (3.82\%, 0.232\%, $103.1 \mathrm{ppm}$ and $29.3 \mathrm{ppm}$ respectively). The higher concentration of copper and manganese content in tomato fruits were noticed in $B$. aryabhattai (10.1 and $46.1 \mathrm{ppm}$ respectively) inoculated treatment at harvest, which is nonsignificantly different.

Effect of zinc solubilizing bacterial isolates on biological activity in tomato rhizosphere at 45 days after planting

The effect of ZSB isolates on soil enzymes activity in the tomato rhizosphere after 45 days of planting significantly increase the dehydrogenase, phosphatase and urease activity (Table 4). Highest dehydrogenase, alkaline phosphatase and urease activity was observed in the treatment inoculated with $B$. aryabhattai $(355.2 \mu \mathrm{g}$ of TPF, $68.9 \mu \mathrm{g}$ of PNP and $24.80 \mu \mathrm{g} \mathrm{NH} \mathrm{NH}_{4} \mathrm{~N}$ released/g soil/hour) followed by the treatment inoculated with Bacillus sp. (PAN-TM1) (298.5 $\mu \mathrm{g}$ of TPF, $66.3 \mu \mathrm{g}$ of PNP and $21.4 \mu \mathrm{g} \mathrm{NH} 4-\mathrm{N}$ released/g soil/hour). 
Table.1 Effect of zinc solubilizing bacterial isolates on rhizosphere nutrient content of tomato at 45DAP

\begin{tabular}{|c|c|c|c|c|c|c|c|c|c|c|c|c|}
\hline Treatments & pH & $\begin{array}{c}\mathrm{EC} \\
\left(\mathrm{dsm}^{-1}\right)\end{array}$ & $\begin{array}{l}\text { OC } \\
(\%)\end{array}$ & $\begin{array}{c}\mathbf{N} \\
(\text { ppm) }\end{array}$ & $\begin{array}{c}\mathbf{P} \\
(\mathbf{p p m})\end{array}$ & $\begin{array}{c}\mathrm{K} \\
(\mathrm{ppm})\end{array}$ & $\begin{array}{c}\mathrm{Ca} \\
(\mathrm{ppm})\end{array}$ & $\begin{array}{c}\mathrm{Mg} \\
(\mathrm{ppm})\end{array}$ & $\begin{array}{c}\mathrm{Fe} \\
(\mathrm{ppm})\end{array}$ & $\begin{array}{c}\mathrm{Cu} \\
(\mathrm{ppm})\end{array}$ & $\begin{array}{c}\text { Mn } \\
(\mathbf{p p m})\end{array}$ & $\begin{array}{c}\mathrm{Zn} \\
(\mathbf{p p m})\end{array}$ \\
\hline B. aryabhattai & 5.95 & 0.734 & 0.79 & 144.1 & 18.9 & 120.2 & 974.1 & 114.5 & 180.2 & 3.1 & 153.7 & 4.27 \\
\hline P. taiwenensis & 6.05 & 0.693 & 0.72 & 116.6 & 16.5 & 102.5 & 910.9 & 113.5 & 161.6 & 3.3 & 152.3 & 3.85 \\
\hline $\begin{array}{c}\text { Bacillus sp. (PAN- } \\
\text { TM1) }\end{array}$ & 6.10 & 0.663 & 0.77 & 140.9 & 18.4 & 107.5 & 956.7 & 113.5 & 113.5 & 3.6 & 160.6 & 3.95 \\
\hline Enterobacter sp.-2 & 6.16 & 0.594 & 0.57 & 92.3 & 14.1 & 82.6 & 763.5 & 102.6 & 101.8 & 3.5 & 149.3 & 2.65 \\
\hline Bacillus aerophilus & 6.34 & 0.596 & 0.66 & 106.9 & 13.8 & 90.1 & 724.3 & 99.8 & 87.3 & 3.6 & 146.2 & 2.6 \\
\hline Un inoculated & 6.52 & 0.577 & 0.49 & 68.04 & 11.9 & 70.3 & 654.2 & 88.5 & 55.6 & 3.3 & 143.1 & 2.2 \\
\hline S.Em \pm & 0.44 & 0.04 & 0.04 & 7.95 & 1.08 & 6.65 & 57.27 & 7.27 & 7.47 & 0.24 & 10.62 & 0.22 \\
\hline CD at $5 \%$ & NS & NS & 0.13 & 23.39 & 3.19 & 19.55 & 168.39 & NS & 21.9 & NS & NS & 0.65 \\
\hline
\end{tabular}

Table.2 Effect of zinc solubilizing bacterial isolates on plant nutrient concentration of tomato (45 DAP)

\begin{tabular}{|c|c|c|c|c|c|c|c|c|c|}
\hline Treatments & $\begin{array}{c}\mathbf{N} \\
(\%)\end{array}$ & $\begin{array}{l}\mathbf{P} \\
(\%)\end{array}$ & $\begin{array}{c}\mathbf{K} \\
(\%)\end{array}$ & $\begin{array}{l}\mathrm{Ca} \\
(\%)\end{array}$ & $\begin{array}{l}\mathrm{Mg} \\
(\%)\end{array}$ & $\begin{array}{c}\mathrm{Fe} \\
(\mathrm{ppm})\end{array}$ & $\begin{array}{c}\mathrm{Cu} \\
(\mathrm{ppm})\end{array}$ & $\begin{array}{c}\mathrm{Mn} \\
(\mathrm{ppm})\end{array}$ & $\begin{array}{c}\mathrm{Zn} \\
(\mathrm{ppm})\end{array}$ \\
\hline B. aryabhattai & 2.45 & 0.65 & 5.2 & 6.86 & 0.396 & 373.6 & 19.1 & 76.6 & 56.3 \\
\hline P. taiwenensis & 2.13 & 0.58 & 4.4 & 4.62 & 0.371 & 327.4 & 14.3 & 77.5 & 48.1 \\
\hline Bacillus sp.(PAN-TM1) & 2.44 & 0.62 & 5.3 & 5.80 & 0.375 & 353.3 & 17.2 & 85.1 & 52.5 \\
\hline Enterobacter sp.-2 & 2.32 & 0.45 & 4.4 & 4.76 & 0.353 & 342.2 & 15.3 & 69.6 & 44.3 \\
\hline Bacillus aerophilus & 1.97 & 0.42 & 3.9 & 4.91 & 0.343 & 335.1 & 15.1 & 74.6 & 42.3 \\
\hline Un inoculated & 1.57 & 0.38 & 2.6 & 4.19 & 0.311 & 298.4 & 13.2 & 45.3 & 37.1 \\
\hline S.Em \pm & 0.14 & 0.03 & 0.29 & 0.35 & 0.02 & 23.66 & 1.10 & 5.02 & 3.19 \\
\hline CD at $5 \%$ & 0.43 & 0.10 & 0.87 & 1.04 & NS & NS & 3.25 & 14.7 & 9.39 \\
\hline
\end{tabular}


Table.3 Effect of zinc solubilizing bacterial isolates on fruit nutrient concentration of tomato at harvest

\begin{tabular}{|c|c|c|c|c|c|c|c|c|c|}
\hline Treatments & $\begin{array}{c}\mathbf{N} \\
(\%)\end{array}$ & $\begin{array}{c}\mathbf{P} \\
(\%)\end{array}$ & $\begin{array}{c}\mathbf{K} \\
(\%)\end{array}$ & $\begin{array}{c}\text { Ca } \\
(\%)\end{array}$ & $\begin{array}{l}\mathrm{Mg} \\
(\%)\end{array}$ & $\begin{array}{c}\text { Fe } \\
(\mathrm{ppm})\end{array}$ & $\begin{array}{c}\mathrm{Cu} \\
(\mathrm{ppm})\end{array}$ & $\begin{array}{c}\text { Mn } \\
(\mathbf{p p m})\end{array}$ & $\begin{array}{c}\mathrm{Zn} \\
(\mathbf{p p m})\end{array}$ \\
\hline B. aryabhattai & 2.36 & 0.34 & 3.58 & 3.89 & 0.233 & 134.1 & 10.1 & 46.1 & 31.1 \\
\hline P. taiwenensis & 1.95 & 0.26 & 3.36 & 3.15 & 0.206 & 98.3 & 08.3 & 46.2 & 26.2 \\
\hline Bacillus sp. (PAN-TM1) & 2.28 & 0.32 & 3.41 & 3.82 & 0.232 & 103.1 & 09.5 & 45.3 & 29.3 \\
\hline Enterobacter sp.-2 & 2.17 & 0.24 & 2.88 & 2.80 & 0.161 & 108.2 & 08.6 & 41.4 & 24.2 \\
\hline Bacillus aerophilus & 1.95 & 0.21 & 2.68 & 2.64 & 0.181 & 96.1 & 08.5 & 44.4 & 20.3 \\
\hline Un inoculated & 1.31 & 0.18 & 2.14 & 2.16 & 0.152 & 85.2 & 08.1 & 35.2 & 17.1 \\
\hline S.Em \pm & 0.13 & 0.01 & 0.20 & 0.21 & 0.01 & 6.87 & 0.62 & 2.92 & 1.68 \\
\hline CD at $5 \%$ & 0.40 & 0.05 & 0.60 & 0.62 & 0.04 & 20.2 & NS & NS & 4.95 \\
\hline
\end{tabular}

Table.4 Effect of zinc solubilizing bacterial isolates on soil enzyme activity in tomato rhizosphere (45 days after planting)

\begin{tabular}{|c|c|c|c|c|}
\hline Treatments & $\begin{array}{c}\text { Dehydrogenase } \\
\text { ( } \mu \mathrm{g} \text { of TPF released /g } \\
\text { soil/hour) }\end{array}$ & $\begin{array}{c}\text { Acid phosphatase } \\
\text { (ug of PNP released /g } \\
\text { soil/hour) }\end{array}$ & $\begin{array}{l}\text { Alkaline phosphatase } \\
\text { ( } \mu \text { g PNP released /g } \\
\text { soil/hour) }\end{array}$ & $\begin{array}{c}\text { Urease } \\
\text { ( } \mathrm{ug} \mathrm{NH}_{4}-\mathrm{N} / \mathrm{g} \\
\text { soil/hour) }\end{array}$ \\
\hline B. aryabhattai & 355.2 & 52.39 & 68.9 & 24.80 \\
\hline P. taiwenensis & 219.5 & 50.07 & 64.8 & 19.24 \\
\hline Bacillus sp. (PAN-TM1) & 298.5 & 50.42 & 66.3 & 21.40 \\
\hline Enterobacter sp.-2 & 257.4 & 50.07 & 58.8 & 18.33 \\
\hline Bacillus aerophilus & 216.4 & 50.60 & 53.4 & 17.64 \\
\hline Un inoculated & 186.6 & 43.73 & 47.6 & 15.98 \\
\hline S.Em & 18.3 & 3.48 & 4.09 & 1.35 \\
\hline $\mathrm{CD}$ at $5 \%$ & 53.9 & NS & 12.04 & 3.99 \\
\hline
\end{tabular}


Table.5 Effect of zinc solubilizing bacterial isolates on soil respiration and soil microbial biomass carbon in tomato rhizosphere (45 days after planting)

\begin{tabular}{|c|c|c|}
\hline Treatment & $\begin{array}{c}\text { Soil respiration } \\
\left(\mathrm{CO}_{2}-\mathrm{C} \mathrm{mg} / \mathrm{kg} \text { soil/hour }\right)\end{array}$ & $\begin{array}{l}\text { Soil microbial biomass carbon( } \mu \mathrm{g} / \mathrm{g} \\
\text { soil })\end{array}$ \\
\hline Bacillus sp.(PAN-TM1) & 16.1 & 1830.1 \\
\hline Enterobacter sp.-2 & 9.7 & 1613.9 \\
\hline Bacillus aerophilus & 10.8 & 1882.2 \\
\hline Un inoculated & 2.6 & 1229.5 \\
\hline S.Em \pm & 0.78 & 121.18 \\
\hline CD at $5 \%$ & 2.31 & 356.28 \\
\hline
\end{tabular}




\begin{tabular}{|l|l|}
\hline & \multicolumn{1}{c}{ Treatment details } \\
\hline $\mathrm{T}_{1}$ & B. aryabhattai $+100 \% \mathrm{~N}$ and $\mathrm{K}, 75 \% \mathrm{P}$ \\
\hline $\mathrm{T}_{2}$ & P. taiwenensis+100\% $\mathrm{N}$ and $\mathrm{K}, 75 \% \mathrm{P}$ \\
\hline $\mathrm{T}_{3}$ & Bacillussp. (PAN-TM1) $+100 \% \mathrm{~N}$ and $\mathrm{K}, 75 \% \mathrm{P}$ \\
\hline $\mathrm{T}_{4}$ & Enterobacter sp. $-2+100 \% \mathrm{~N}$ and $\mathrm{K}, 75 \% \mathrm{P}$ \\
\hline $\mathrm{T}_{5}$ & Bacillus aerophilus $+100 \% \mathrm{~N}$ and $\mathrm{K}, 75 \% \mathrm{P}$ \\
\hline $\mathrm{T}_{6}$ & Un inoculated Control $+100 \% \mathrm{NPK}$ \\
\hline
\end{tabular}

There was no significant difference noticed in acid phosphatase activity among different zinc solubilizing bacterial isolates, however, the highest activity recorded in $B$. aryabhattai (52.39 $\mu \mathrm{g}$ of PNP released/g soil/hour) treatment.

Effect of zinc solubilizing bacterial isolates on soil respiration and soil microbial biomass carbon in tomato rhizosphere after 45 DAP

Significant differences in soil respiration and soil microbial biomass carbon was observed in rhizosphere of Tomato as influenced by the ZSB isolates after 45 days of planting (Table 5). Maximum soil respiration was recorded in the treatment inoculated with Bacillus sp. (PANTM1) (16.1 $\mathrm{CO}_{2}-\mathrm{C} \mathrm{mg} / \mathrm{kg}$ soil/hour) followed by $B$. aryabhattai $\quad\left(12.5 \quad \mathrm{CO}_{2}-\mathrm{C} \quad \mathrm{mg} / \mathrm{kg}\right.$ soil/hour), whereas treatment inoculated with $B$. aryabhattai (1982.3 $\mu \mathrm{g} / \mathrm{g}$ soil) recorded the highest soil microbial biomass carbon. The least soil respiration and soil microbial biomass carbon was recorded in the uninoculated control.

Zinc is an essential nutrient for not only improving crop productivity, but also to alleviate malnutrition in human populations and provide nutritional security. Zn deficiency has become a serious problem affecting nearly half of the world's population (Cakmak, 2008). This is actually due to fixation of major portion of available form of $\mathrm{Zn}$ caused by chemical reactions which leads to the crops grown in $\mathrm{Zn}$ deficient soils. Many Indian soils exhibit the deficiency of $\mathrm{Zn}$ with the content much below the critical level of $1.5 \mathrm{ppm}$ (Tiwari and Dwivedi, 1994). It is expected to increase from $42 \%$ in 1970 to $63 \%$ by 2025 due to continuous depletion of soil fertility (Singh, 2009). To overcome zinc malnutrition, there are many interventions that help in increasing the dietary zinc intakes. One such intervention is through the exploitation of soil microorganisms that can mobilize unavailable zinc, increase zinc assimilation, plant growth and yield. Pot culture screening experiments are very much essential for analyzing the effects of microbial bio inoculants on various plant growth parameters as well as on nutrient uptake before evaluating their efficacy under field conditions. In the present study, five zinc solubilizing bacterial isolates were inoculated individually Tomato plants improved nutrient concentration in rhizosphere soil, plant and fruit of Tomato and also soil enzymes activitiy.

B. aryabhattai inoculated treatment reduced the soil $\mathrm{pH}$ their by significantly increased the major and minor nutrients in the soil. Similar decrease in the rhizospheric $\mathrm{pH}$ with the inoculation of Bacillus cereus W9 and Bacillus sp. was previously reported by Yu et al., (2011). This might be attributed to excretion of organic anions is often associated with proton extrusion, leading to a substantial lowering of rhizosphere pH (Neumann and Romheld, 2002). In addition to the change in rhizospheric $\mathrm{pH}$, production of organic acids can also directly facilitate the mobilization of nutrients by reducing sorption of nutrients by altering the surface charge characteristics of soil colloids, desorption of nutrients from sorption sites (Jones, 1998), which helps in the uptake of macro and micro nutrients by the plants and leads to accumulation of nutrients in different parts of the plants (Dahaji et al., 2012 and Desai et al., 2012). Similarly, inoculation of maize with Pseudomonas and Bacillus significantly 
increased the nutrient content of $\mathrm{N}, \mathrm{P}, \mathrm{K}, \mathrm{Fe}$, $\mathrm{Cu}, \mathrm{Mn}$, and $\mathrm{Zn}$ content in maize leaves by applying PGPR (Puente et al., 2004). Thus ZSB strains proved to have a favorable effect on the availability of major and minor nutrients in the rhizosphere soil which helps in uptake by plants.

Inoculation of ZSB strains significantly increased macro and micro nutrient concentration in tomato fruit. B. aryabhattai inoculated treatment recorded highest major and minor nutrient concentration, especially $\mathrm{Zn}$ concentration in tomato fruit (31.1ppm). Similarly inoculation of $B$. aryabhattai to soyabean and wheat crop significantly increased the zinc concentration in soyabean seed and wheat grain between 49.70 and $61.25 \mathrm{mg} / \mathrm{kg}$ (Ramesh et al., 2014). Mader et al., (2011) also reported a substantial increase in $\mathrm{Mn}$ and $\mathrm{Zn}$ concentration in rice grains due to application of combination of natural mycorrhiza consortia and fluorescent Pseudomonas strain R62 + R81. Roesti et al., (2006) and Mader et al., (2010) had reported that inoculation of Pseudomonas synxantha HHRE81 (R81) and P. jessenii LHRE62 (R62) increased zinc concentration in seeds of wheat and black gram. In another study, Tariq et al., (2007) demonstrated the efficiency of a commercial PGPR consortium acting as zinc solubilizer that increased $\mathrm{Zn}$ concentration to an extent of $157 \%$. The results are mainly due to higher enzyme activities, microbial biomass-C, significant drop in rhizosphere $\mathrm{pH}$, and redistribution among native zinc pools resulting in increased zinc availability for crop acquisition. Many reports indicated that the zinc concentration is too low to meet the daily human requirement in regions solely dependent on cereal based diet (Cakmak, 2008). In our present study the zinc concentration in tomato fruit is the above the minimum requirements needed for daily human requirements. The increased zinc concentration found in this study has large implications in terms of overcoming zinc malnutrition of the rural Indian population, wherein, zinc malnutrition is wide spread.
Soil enzyme activities have been used as an early and sensitive indicator to soil perturbations like, tillage, addition of organic manure, crop rotation and microbial inoculation and are reflection of ecosystem functioning (Sharma et al., 2010). In this regard, efforts were made to determine changes in rhizosphere enzyme activities pertinent to zinc cycling as a consequence of inoculation with ZSB strains to Tomato crop. Significant increase in the dehydrogenase activity, phosphatase activity, urease activity, soil respiration and microbial biomass carbon in $B$. aryabhattai inoculated treatment as compared to uninoculated control. The results are mainly due to the availability of a high quantity of biodegradable substrates, provide simple sugars for the soil microbial population and are explicitly related to soil functions such as nutrient cycling (Stott et al., 2010). The study revealed an increase in microbial respiration with inoculation in the rhizosphere soils indicates the oxidative capacity of soil microorganisms influenced both by the energy sources that there are in the soil and the number of microorganisms in the soil (Bastida et al., 2008). Inoculation with $B$. aryabhattai strains also significantly increased microbial biomass- $\mathrm{C}$ in the rhizosphere of tomato making it a useful index for diagnosing early changes in soil $\mathrm{C}$ stabilization and nutrient dynamics following perturbation (Joergensen and Emmerling, 2006).

From the present study we can clearly conclude that among the different ZSB isolates, $B$. aryabhattai and Bacillus sp. (PAN-TM1) strains were found to be the most promising zinc solubilizing bacterial isolates based on polyphasic approaches. Inoculation of these isolates decreased rhizosphere $\mathrm{pH}$ and increased biological activity in the rhizosphere of tomato crop. This intense microbial activity in rhizosphere resulted in a depletion of organically complexed, bound zinc and calcium carbonate bound zinc thus increased in the concentration of zinc and other nutrients. As a result, better uptake and accumulation of nutrients in different parts of the tomato crop was observed. Hence, these ZSB isolates can be 
promoted as potential bio-inoculants to mitigate zinc deficiency in soils after proper field evaluation and validation.

\section{References}

Baruah, T. C. and Barthakur, H. P., 1997. In Textbook of Soil Analysis. Vikas Publications Pvt Ltd. New Delhi.

Bastida, F., Barbera, G., Garcia, C. and Hernandez, T., 2008. Influence of orientation, vegetation and season on soil microbial and biochemical characteristics under semiarid conditions. Appl. Soil Ecol. 38: 62-70.

Bray, R. H. and Kurtz, L. T., 1945. Determination of total organic and available forms of phosphorus in soils. Soil Sci. 59: 39-45.

Cakmak, I., 2000. Role of zinc in protecting plant cells from reactive oxygen species. New Phytol.146: 185-205.

Cakmak, I., 2008. Enrichment of cereal grains with zinc: agronomic or genetic biofortification? Plant Soil. 302: 1-17.

Dehaji, A. P., Ehaji, P., Savaghebi, G. H., Rahmani, H. S., Rejali, F., Farahbakhsh, M., Motesharezadeh, B. and Omidvari, M., 2012. Effect of Fluorescent psuedomonads on improving zinc compounds solubility and zinc uptake by common bean (Phaseolus vulgaris L). Iranian. J. Soil. Res. 26 (2): 195-206.

Desai, S., Praveen Kumar, G., Sultana, U., Pinishetty, S., Ahmed, M. H., Amalraj, D. L. and Goppal Reddy., 2012. Potential microbial candidate strain for management of nutrient require of crops. African. J. Microbiol. Res. 6 (17): 39243921.

Eivazi, F. and Tabatabai, M. A., 1977.Phosphatases in soils. Soil BiolBiochem. 9: 167-177.

Fageria, N.K., Baligar, V.C. and Clark, R.B., 2002. Micronutrients in crop production.Adv. Agron.77: 185-268.

Jackson, M. L., 1973. Soil chemical analysis, Prentice Hall of India (Pvt.) Ltd. New Delhi.
Jenkinson, D.S., 1988. The determination of microbial biomass carbon and nitrogen in soil. In: Wilson, J.R. (Ed.), Advances in Nitrogen Cycling in Agricultural Ecosystems. CAB International, Wellingford, pp. 368-386.

Joergensen, R.G. and Emmerling, C., 2006. Methods for evaluating human impact on soil microorganisms based on their activity, biomass, and diversity in agricultural soils. J. Plant Nutr. Soil Sci. 169: 295-309.

Jones, D.L., 1998. Organic acids in the rhizosphere -a critical review. Plant Soil.205:25-44.

Lindsay, W. L. and Norwell, W. A., 1978.Development of a DTPA soil test for zinc, iron, manganese and copper. Soil Sci. American. J. 42: 421-428.

Mader, P., Kaiser, F., Adholeya, A., Singh, R., Uppal, H.S., Sharma, A.K., Srivastava, R., Sahai, V., Aragno, M., Wiemken, A., Johri, B.N. and Fried, P.M. 2011. Inoculation of root microorganisms for sustainable wheat rice and wheat black gram rotations in India. Soil. Biol. Biochem. 43: 609-619.

Mader, P., Kiser, F., Adholeya, A., Singh, R., Uppal, H.S., Sharma, A.K., Srivastava, R., Sahai, V., Aragno, M., Wiemkein, A. Johri, B.N. and Fried, P.M., 2010. Inoculation of root microorganisms for sustainable wheat -rice and wheat-black gram rotations in India. Soil Biol. Biochem. 43: 609-619.

Neumann, G. and Romheld, V., 2002. Root induced changes in the availability of nutrients in the rhizosphere. In: Waisel, Y., Eshel, A., Kafkafi, U. (Eds.), Plant Roots: The Hidden Half. Marcel Dekker, New York. pp. 41-93.

Piper, C.S., 1966.Soil and plant analysis. Hans publishers Bombay.

Potarzycki, J. and Grzebisz, W., 2009. Effect of zinc foliar application on grain yield of maize and its yielding components. Plant Soil Environ. 55(12): 519-527.

Puente, M. E., Li, C. Y. and Bashan, Y., 2004. Microbial populations and activities in the 
rhizoplane of rock weathering desert plants. II. Growth promotion of cactus seedlings. Plant Biology. 6: 643-650.

Ramesh, A., Sharma, S. K., Sharmaa, M. P., Yadava, N. and Joshi, O. P., 2014.Inoculation of zinc solubilizing Bacillus aryabhattai strains for improved growth, mobilization and biofortification of zinc in soybean and wheat cultivated in vertisols of central India. Appl. Soil. Ecol. 73: 87-96.

Rattan, R. K. and Shukla, L. M., 1991. Influence of different zinc carrier on the utilization of micro nutrients by rice. $J$. Indian Soc. Soil Sci. 39: 808-810.

Roesti, D., Gaur, R., Johri, B.N., Imfeld, G., Sharma, S., Aragno, M. and Kawaljeet, 2006.Plant growth stage, fertilizer management and bioinoculant of arbuscular mycorrhizal fungi and plant growth promoting rhizobacteria affect the rhizobacterial community structure in rainfed wheat fields. Soil Biol. Biochem.38: 1111-1120.

Saravanan, V. S., Subramoniam, S. R., and Anthoni raj, S., 2003. Assesing in vitro solubilisation potential of different zinc solubilising bacterial isolates. Brazilian. J. Microbiol. 34: 121-125.

Sharma, S.K., Ramesh, A., Sharma, M.P., Joshi, O.P., Govaerts, B., Steenwerth, K.L. and Karlen, D.L., 2010. Microbial community structure and diversity as indicators for evaluating soil quality. In: Lichtfouse, E. (Ed.), Biodiversity, Biofuel, Agroforestry and Conservation Agriculture, Sustainable Agriculture Review 5. Springer Science + Business Media B.V, The Netherlands. pp. 317-358.
Singh, M.V., 2009. Evaluation of current micronutrient stocks in different Agro Ecological zones of India for sustainable crop production. Fert. News. 46: 25-42.

Stott, D.E., Andrews, S.S., Leibig, M.A., Wienhold, B.J. and Karlen, D.L., 2010. Evaluation of $\beta$-glucosidase activity as a soil quality indicator for the soil management assessment framework. Soil Sci. Soc. Am. J. 74: 107-119.

Subbaiah, B.V. and Asija, G.L., 1956. A rapid procedure for the estimation of available nitrogen in soils. Curr. Sci. 25: 259-260.

Tabatabai, M.A and Bremner, J.M., 1972. Assay of urease activity in soils. Soil Biol. Biochem. 4: 479-487.

Tariq, M., Hameed, S., Malik, K.A. and Hafeez, F.Y., 2007. Plant root associated bacteria for zinc mobilization in rice. Pak. J. Bot. 39(1): 245- 253.

Tate, R.L. and Terry, R.E., 1980. Variation in microbial activity in histosols and its relationship to soil moisture. Appl. Environ. Microbiol. 40: 313-317.

Tiwari, K. N. and Dwivedi, B. S., 1994.Available zinc status of soils and delineation of the areas of zinc deficiency in Uttar Pradesh. Fert. News. 39(3): 3139.

Vance, E.D., Brookes, P.C. and Jenkinson, D.S., 1987. An extraction method for measuring soil microbial biomass C. Soil Biology \& Biochemistry. 19: 703-707.

Yu, X., Liu, X., Zhu, T.H., Liu, G.H. and Mao, C., 2011. Isolation and characterization of phosphate solubilizing bacteria from walnut and their effect on growth and phosphorus mobilization. Biol. Fertil. Soils. 47: 437-444.

\section{How to cite this article:}

Vidyashree, D.N., R. Muthuraju and Panneerselvam, P. 2018. Nutrient Uptake and Biological Activity in Tomato by Zinc Solubilizing Bacterial (ZSB) Isolates. Int.J.Curr.Microbiol.App.Sci. 7(05): 472-484. doi: https://doi.org/10.20546/ijcmas.2018.705.059 